\title{
Ecology and nesting biology of the wood-boring bee Trichothurgus laticeps (Hymenoptera: Megachilidae) in a Monte desert reserve in mid-western Argentina
}

\author{
Nydia Vitale ${ }^{1}$, Diego P. VÁzQuez ${ }^{1,2}$ \\ ${ }^{1}$ Instituto Argentino de Investigaciones de las Zonas Áridas, CONICET, 5500, Mendoza, Argentina \\ ${ }^{2}$ Facultad de Ciencias Exactas y Naturales, Universidad Nacional de Cuyo, M5502JMA, Mendoza, Argentina \\ Received 14 January 2016 - Revised 17 March 2016 - Accepted 31 March 2016
}

\begin{abstract}
Studying bee nests can enlighten our understanding of feeding specialization and phylogenetic relationships of bees. We studied the nesting and feeding habits of Trichothurgus laticeps in the Monte desert ecosystem. Our results show that $T$. laticeps is attracted to pre-existing cavities in wood (trap nests), which were further excavated for nest construction; nest cells are unlined and provisioned almost exclusively with pollen of the cactus Opuntia sulphurea. The species overwinters inside a hard cocoon. Our results reinforce the hypothesis previously proposed by other authors that the unworked pollen mass and oligolecty are plesiomorphic characters in the Megachilidae, and that the wood-boring behavior for nest construction indicates convergent evolution with the Xylocopinae. We also propose that the cocoon structure might represent an evolutionary novelty for the Lithurginae.
\end{abstract}

host-plant specialization / Lithurginae / nesting behavior and structure / phylogenetic relationships / solitary bees

\section{INTRODUCTION}

The study of bee nests, including their architecture, the structure of brood cells, the type of provisions, and larval behavior, may enhance our understanding of the ecology and evolution of bees (Michener 2007). The Megachilidae is an imposing bee family, with over 4000 described species (Ascher and J. Pickering 2010). Phylogenetic studies suggest this family is monophyletic (Danforth et al. 2013; Hedtke et al. 2013; Litman et al. 2011; Roig-Alsina et al. 1993) with four subfamilies: Fideliinae, Lithurginae, Pararhophitinae, and

Electronic supplementary material The online version of this article (doi:10.1007/s13592-016-0446-6) contains supplementary material, which is available to authorized users.

Corresponding author: N. Vitale,

nydiavitale@yahoo.com

Manuscript editor: Klaus Hartfelder
Megachilinae (Danforth et al. 2013; Hedtke et al. 2013). It is accepted that Fideliinae is the sister clade to the remainder of the family (Danforth et al. 2013; Hedtke et al. 2013; Litman et al. 2011; Michener 2007). While morphological studies (Gonzalez et al. 2012) indicate that the Pararhophitinae are more basal than the Lithurginae, molecular studies are less conclusive, given that both groups exhibit several plesiomorphic characters (Hedtke et al. 2013; Litman et al. 2011).

Studying bee nests can also illuminate our understanding of feeding specialization in bees. Although a number of bee species have been identified as purported pollen specialists (e.g., Neff 2003; Neff and Simpson 1992), in many cases, this conjecture rests primarily on visitation observations or scopal pollen loads, which usually represent a single foraging trip (Sipes and Tepedino 2005). In contrast, pollen provisions in bee nests offer copious information on the foraging habits of female 
bees, integrating their resource use in space and time. Several studies have so far attempted to evaluate pollen specialization in bees using pollen provisions in brood cells (Bosch et al. 1993; Buschini et al. 2009; Dórea et al. 2013; Gonçalves et al. 2012; Rust et al. 2004; Schlindwein et al. 2009).

The available information on nesting and feeding habits is extremely limited for some groups in the Megachilidae, which hinders our understanding of their phylogenetic relationships. This is the case for the Lithurginae, for which the information on nesting habits is particularly limited. This subfamily includes four genera: Lithurgus, Lithurgopsis, Microthurge, and Trichothurgus . There is information about the nesting biology of the former three genera from several studies, with at least 12 studies on Lithurgus and Lithurgopsis species (Rozen 2013; Rozen and Hall 2014), one study on one Microthurge species (M. corumbae; Garófalo et al. 1992), and additional notes on the occurrence of other species in South America (Ascher and J. Pickering 2010; Moure and Melo 2012). Most species in these three genera excavate their burrows in wood and construct their nests with unlined brood cells (Rozen 2013); trophically, they range from oligolectic, feeding on few plant species (Díaz and Cocucci 2003), to polylectic, feeding on many plant species of multiple families (Güler and Sorkun 2007). The information available for Trichothurgus is comparatively rather limited, coming from anecdotal nesting observations of T. dubius (Claude-Joseph 1926; Rozen 1973) and a study of $T$. bolithophilus in which this species was observed nesting in dry horse dung (Sarzetti et al. 2012). Although Trichothurgus species were believed to feed primarily on pollen from cactus (Michener 2007), T. bolithophilus was recorded feeding primarily on pollen from the Asteraceae and Amaranthaceae (Sarzetti et al. 2012). Thus, it is unclear whether the anecdotic records of the nest building and provisioning habits of T. dubius and T. bolithophilus are representative of the diversity of nesting habits of Trichothurgus, and whether the above observations indicate a departure from the wood nesting habits of Lithurgus and Microthurge. Answering these questions should improve our understanding of the evolution of the nesting habits of lithurgine bees and of the phylogenetic relationships within this group and with other bee groups.
Our study focuses on Trichothurgus laticeps Friese, 1906, a species occurring in xeric regions of Argentina. We studied the foraging and nesting biology of $T$. laticeps, including cell provisions, cocoon structure, and nest architecture.

\section{MATERIAL AND METHODS}

\subsection{Study sites and field methods}

Data used in this study come from field studies conducted between 2006 and 2012 in the Monte Desert of Villavicencio Nature Reserve, Mendoza, Argentina (Chacoff et al. 2012; Dorado 2011; Vázquez et al. 2009, 2012; Table I). Because data come from several projects running simultaneously at the same sites, there are minor differences in the sampling methods used in different years. In 2006 and 2007, four sample sites were located near a dry temporary stream at ca. $1240 \mathrm{~m}$ above sea level. In 2008, data were collected at 18 sites located at different elevations above sea level (range 1078-1450 m), post fire age (range 1-50+ years), and vegetation types. In 2009-2011, data were collected at six sites located at $1115-1750 \mathrm{~m}$ above sea level. Additional sites were included in 2012, expanding the elevational range of the studies.

Data on pollinator visitation to flowers came from a study conducted between 2006 and 2011 (Chacoff et al. 2012 and additional unpublished results). Pollinator visits to flowers were recorded in the spring and early summer (September to December or January) in six consecutive flowering seasons. We recorded flower visiting insects on plant species in weekly surveys, sampling the whole community as comprehensively as possible (see Chacoff et al. 2012 for further details on sampling methods).

Bees were studied using wooden trap nests. Each study site was a $200 \times 100 \mathrm{~m}$ rectangular area with six sampling points separated by $100 \mathrm{~m}$. Each sample point consisted of two poles separated by $10 \mathrm{~m}$. Each pole contained 24 traps of three different sizes: eight traps of $14 \mathrm{~cm}$ hole length and $0.5 \mathrm{~cm}$ of hole diameter, eight traps measuring $14 \mathrm{~cm} \times 0.8 \mathrm{~cm}$, and eight traps measuring $28 \times 1.1 \mathrm{~cm}$; the smaller traps were placed at $0.70 \mathrm{~m}$ from the ground, the longer at $0.40 \mathrm{~m}$. All study sites were visited weekly to conduct plant abundance surveys and to collect nests in the spring and summer, the flowering and bee activity season in the study area. We used all data sets to describe the natural history of 
Table I. Resume of study aims and data use for the T. laticeps nest sites in a Monte desert reserve.

\begin{tabular}{llll}
\hline Aim & Year & Number of sites & Number of nests built \\
\hline Natural history (whole study) & $2007-2012$ & 21 & 221 \\
Phenology & 2009 & 1 & 11 \\
Visits to flowers (census) & $2006-2011$ & 2 & - \\
$\begin{array}{l}\text { Temporal co- } \\
\text { occurrence }\end{array}$ & $2007-2012$ & 2 & 42 \\
$\begin{array}{l}\text { Spatial co- } \\
\text { occurrence }\end{array}$ & 2008 & 18 & 21 \\
$\begin{array}{c}\text { Larval pollen } \\
\text { provision }\end{array}$ & $2008-2009$ & 11 & 80 \\
Parasite attack & 2012 & 1 & 1 \\
\hline
\end{tabular}

T. laticeps collected between 2008 and 2012 in the sites described above. For the analysis of plant/bee spatial co-occurrence, we used the 2008 data. To study interannual variation in nesting habits, we used the 20082011 data for the two sites for which we had uninterrupted records from trap nests. Information on the unique parasitic relationships comes from one of the 2012 sites (1965 m above sea level). Finally, to study intra-annual nesting phenology, we used the 2009 data (Table I).

\subsection{Laboratory methods}

Once nests were built (once adult female nest activity had ended), they were taken to the laboratory and kept at ambient environmental conditions until adult emergence. We extracted a pollen sample from some nests (total 80 samples, 71 nests in 2008 and 9 nests in 2009) for pollen grain identification. Taxonomic identification of pollen was conducted using the so-called natural method (Louveaux et al. 1978; Maurizio et al. 1978) by light microscopic comparison with a reference collection. The latter included all flowering plant species recorded in our study plots.

\subsection{Data analyses}

All statistical analyses were performed with $\mathrm{R}$ statistical software, version 3.2.0 (R Core Team 2015). Plots were drawn with R's ggplot2 package version 0.9.3.1 (Wickham 2009). To estimate species' degree of specialization, we used the specialization index $d$ (Blüthgen et al. 2006), calculated with the species level function of R's package bipartite. The index $d$ measures the deviation from randomly distributed interactions, and varies between 0 (extreme generalization) and 1 (extreme specialization).

To evaluate whether nests differed in their pollen composition and fitness, we used one-way, parametric ANOVA when the data met the assumptions of the test, or the Kruskal-Wallis test when data did not meet such assumptions. We used three variables to estimate female reproductive success: the length of the pollen mass (which should correlate with the number of eggs laid), the number of cocoons built, and the number of adults emerged per nest.

To assess the degree of resource specialization of T. laticeps, we quantified individual- and population-level specialization using the WTdMC function of the RInSp package of R statistical software (Zaccarelli et al. 2013). This function calculates total niche width (TNW) and the withinindividual component (WIC) indices (Roughgarden 1974). TNW is an estimate of the total niche width of the population, while WIC/TNW is an estimate of the proportion of TNW explained by withinindividual variation. Thus, TNW tends to zero when the whole population uses a unique source. In turn, WIC/TNW approaches 1 when all individuals use the full range of the population's niche, whereas smaller values indicate decreasing inter-individual overlap and hence higher individual specialization (Sargeant 2007).

To evaluate whether the presence of T. laticeps was related to the presence of Opuntia sulphurea 
(Opuntiaceae) in our study sites in 2008 (the year in which we studied the greatest number of sites), we used a $\chi^{2}$ test with function chisq.test of the stats package of $\mathrm{R}$; as data did not meet the assumptions of the test, we calculated statistical significance by simulation, using the option simulate.p.value $=$ TRUE of function chisq.test . We used the same $\chi^{2}$ test to evaluate whether the temporal occurrence of flowering (phenology) of $O$. sulphurea was related to the temporal occurrence of nesting of $T$. laticeps.

\section{RESULTS}

\subsection{Interaction with plants}

Between 2006 and 2011, T. laticeps was recorded visiting flowers of two out of 54 plant species on which visitation observations were conducted: O. sulphurea (Opuntiaceae; 18 out of 22 visits, $82 \%$; Supplementary Material Fig. S1A) and Zuccagnia punctata (Fabaceae; 4 visits, $18 \%$ ). The specialization index of T. laticeps was $d=0.48$, which placed it among the $16 \%$ most specialized species of flower visitors in this community (mean $\pm \mathrm{SD}$ of $d 0.31$ \pm 0.18 ; range $0-0.87$ ) when considering only flower visitation observations (but see below results of nest pollen analysis).

When visiting flowers of $O$. sulphurea, female $T$. laticeps usually lied sideways to enter the flower's corolla under the stamina, staying in this position for the whole duration of the visit. Presumably, this rather unusual position may help the bee avoid the stamina (Schlindwein and Wittmann 1997), as many Opuntia species are known to move them in response to a mechanical stimulus (Spegazzini 1900), a behavior also observed in O. sulphurea (R. Kiessling, pers. comm.).

O. sulphurea was by far the most common species in nest pollen provisions, representing by 90-100\% of pollen content in all nests (Figure 1). In this sense, $T$. laticeps appears to be highly oligolectic. However, most nests had ca. $5 \%$ of pollen of either Prosopis flexuosa (Fabaceae; $70 \%$ of nests) or Cerastium arvense (Caryophyllaceae; $20 \%$ of nests). Other species occurred rarely, including Larrea spp.

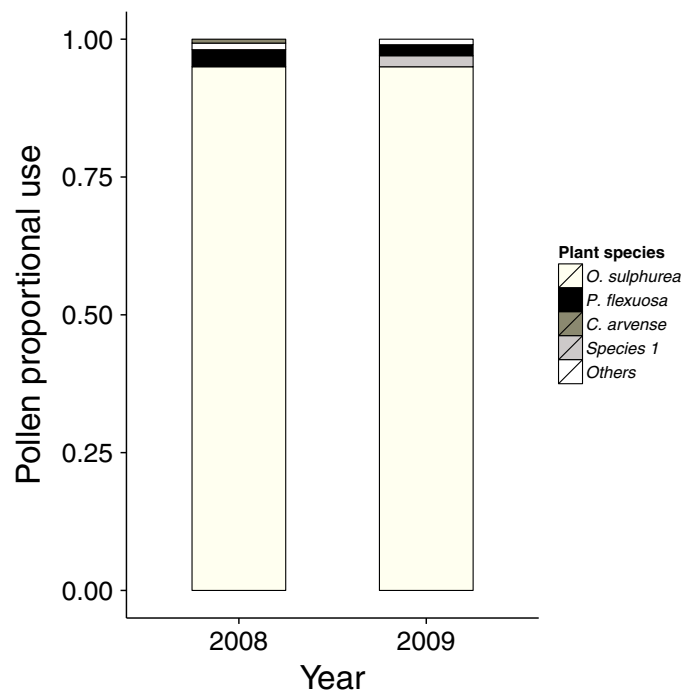

Figure 1. Rate of pollen use for larval provision by the bee Trichothurgus laticeps in two study years (71 nests examined in 2008 and 9 in 2009).

(Zygophyllaceae), Sphaeralcea mendocina and Lecanophora heterophylla (Malvaceae), Acantholippia seriphioides (Verbenaceae), Pyrrhocactus sp. (Opuntiaceae), Capparis atamisquea (Capparaceae), and Senna aphylla (Fabaceae). The rare but pervasive presence of $P$. flexuosa and $C$. arvense had no significant effects on any of the three proxies of female reproductive success: length of pollen mass (ANOVA: $F=0.95, d f=4, P=0.4372$ ), number of cocoons built (ANOVA: $F=1.86$, $d f=4, P=0.1254$ ), and number of adults emerged per nest (ANOVA: $F=0.60, d f=4$, $P=0.6625)$.

Roughgarden's (1974) specialization indices also indicate oligolecty. TNW was rather small (2008: TNW $=0.24 ; 2009$ : $\mathrm{TNW}=0.26$ ), suggesting high specialization. This high population-level specialization did not result from individual specialization on different resources, as WIC/TNW was relatively high (2008: WIC/TNW $=0.85 ; 2009$ : $\mathrm{WIC} / \mathrm{TNW}=0.76$ ). Thus, the population as a whole appears to be specialized on few floral resources, with relatively substantial overlap among individuals in their feeding habits. 
The strong association of $T$. laticeps to $O$. sulphurea indicated by the extremely high proportion of pollen of this species in nests was also evident by the patterns of spatial co-occurrence between the two species. Spatially, T. laticeps was absent from all sites without $O$. sulphurea, and present only in sites with this plant species, even if extremely rare. This pattern of spatial cooccurrence was highly significant $\left(\chi^{2}=8.56\right.$, $d f=1 ; P=0.031)$. Temporally, we observed a similar pattern, with no nests recorded before the first flower of $O$. sulphurea observed in the field (no negative delay between starts bee minus plant event was observed), despite high inter-annual variability in weather conditions (Figure 2). Again, this pattern was highly significant $\left(\chi^{2}=18.81, d f=1\right.$, $P=0.0015)$. The mean duration of flowering time in $O$. sulphurea was 40 days (range $=14-63$ days), and the mean duration of nesting activity in $T$. laticeps was 29 days (range $=1-69$ days).



Figure 2. Phenological delay between $T$. laticeps and O. sulphurea. Delay is defined as the time of an event's occurrence (start, peak, or end) for the bee minus the time of occurrence of the corresponding event for the plant. Full line: start (first nest built or flower observed); dashed line: peak (maximum recorded number of nests or flowers); dotted line: end (last nest built recorded or flower observed).

\subsection{Nesting phenology}

Of the 80 trap nests set up to study nesting phenology in 2009, only 11 were occupied by T. laticeps, one of them shared with Anthidium vigintipunctatum (Hymenoptera: Megachilidae). Two of these nests were lost to attacks by unidentified ants. In the remaining nine nests, the length of the egg/feeding larval period was 2-6 weeks, after which (between late December and late January) each larva built a cocoon and entered diapause. In all but two nests, provisioning was complete by early to mid-December, overlapping completely with the flowering period of $O$. sulphurea. The other two nests were detected in the late summer in the cocoon stage; based on their developmental times, they were presumably built in January, and several weeks after the flowering of $O$. sulphurea had ended. Interestingly, the number of cells in these two nests was lower than in the other seven nests (mean 5.5 cells per nest vs. 11.6 cells per nest, respectively).

Immature stages in most nests spent only one winter in diapause, so that adults emerged in the following spring (Figure 3). However, some adults emerged after two winters (e.g., $25 \%$ nests in $2008,13 \%$ in 2009).

\subsection{Nest architecture}

Although females of $T$. laticeps occupied the preexisting cavities in our trap nests, they widened the hole by tearing wood with their mandibles. It is important to point out here that because our trap nests had only one longitudinal cavity (Fig. S1C-E), all nests recorded in our trap nests were longitudinal; however, we observed in a few nests signs of lateral burrowing activity, indicating that females may have tried to branch the nest. Of the three hole diameters used in our study, the smallest was never used by T. laticeps, as it probably was too small for the adult female. In addition to trap nests, we also found one natural nest of $T$. laticeps in a dead branch of the exotic tree Schinus molle var areira (L.) DC. (Anacardiaceae). We followed the female's activity during nesting provisioning for 2 weeks, but unfortunately, the branch of the tree where the nest was 


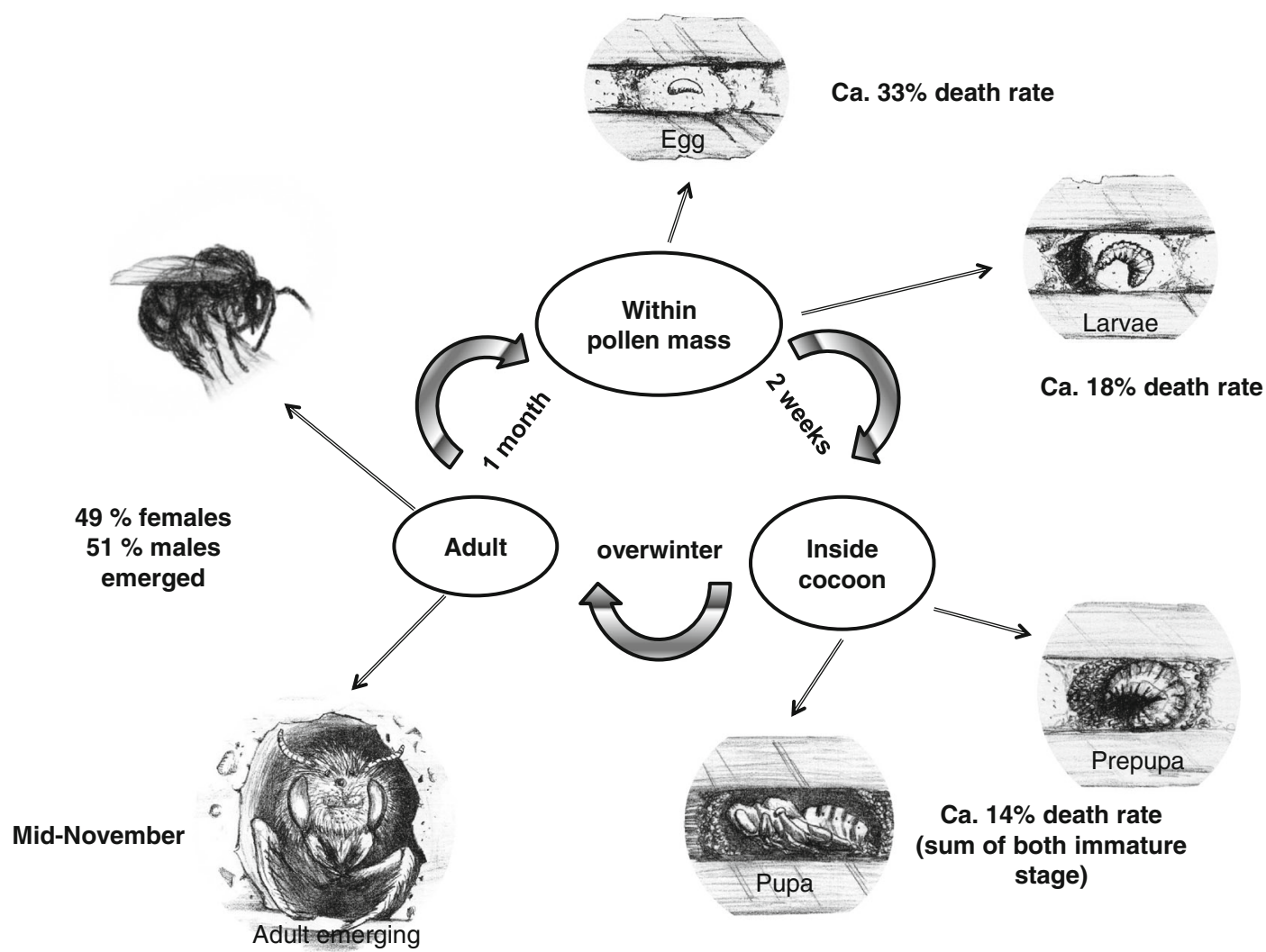

Figure 3. Developmental phenology of T. laticeps based on 11 nests. Drawings by Federico Dellagnola.

located was pruned afterwards, which prevented us from pursuing these observations further.

All nests lacked a closure at the entrance of the nest, which allowed seeing the pollen from the outside. The cells of all nests were unlined wood cavities filled with continuous pollen mass. Eggs were laid at roughly regular distances $(\mathrm{ca} .2 \mathrm{~cm}$ ) within the pollen mass (Fig. S1C). Only a handful of nests had vertical partitions, made with wood pieces and pollen. Pollen was fairly dry and loose and lacked cohesiveness, breaking apart easily when removed from the nest; however, pollen around eggs was wet and hardened. For approximately two weeks after eggs were laid larvae feed from pollen matrix (Fig. S1D). By the time cocoons had been built, most pollen had been consumed by larvae, and cocoons were surrounded by abundant feces and pollen remains (Fig. S1E). The cocoon is oval (maximum diameter 2 $\pm 0.5 \mathrm{~cm}$ ), brown and rough, lacking a nipple (protruding thickened spot), and is as broad as the tunnel diameter $(0.8$ or $1.1 \mathrm{~cm}$ in our study). The cocoon's coat has two layers: the inner layer is brown, thin, and smooth; the outer layer is coarse and hard, covered by larval feces. This coat is harder than in other solitary bees present in the study site and was extremely resistant to the pressure applied by the observers' fingers.

In the 11 nests studied in 2009 to describe intra-annual nesting phenology, the nest pollen mass occupied on average ca. $75 \%$ of the available space in the trap nest cavity. Nests had an average of eight eggs (range 2-16). Of the original eggs laid in nests, $33 \%$ died during the egg stage, $18 \%$ died in the larval stage, and $14 \%$ died inside the cocoon; only $46 \%$ eggs reached the adult stage in the lab, $49 \%$ of which were females (Figure 3). 


\subsection{Nest associates}

Although other species of solitary bees, wasps, beetles, spiders and their parasites, occupy nests of other bee species in our study area, T. laticeps shared the nest cavity rarely with two other solitary bee species: the carder bee $A$. vigintipunctatum ( $0.06 \%$ nests in all years) and the carpenter bee Xylocopa atamisquensis $(0.05 \%$ nests in all years). Nest development did not seem to be affected by such coexistence.

A few nests of $T$. laticeps were attacked by unidentified ants during the egg stage, after which development stopped; however, the proportion of attacked nests was low in all years of study $(0.01 \%$ from 83 nests in 2008, $0.15 \%$ from 35 nests in 2009, $0.03 \%$ from 23 nests in 2010, and $0.05 \%$ from 36 in 2011).

We found only one cleptoparasite species in our study, Leucospis hopei Westwood, 1834 (Hymenoptera: Chalcidoidea; Fig. S1B). Seven parasite individuals emerged from one single trap nest; amidst the cocoon debris, we found dead T. laticeps larvae that presumably died soon after cocoon construction. It is worthy of note that this nest came from the highest study site, located at $1965 \mathrm{~m}$ above sea level.

\section{DISCUSSION}

Our results indicate that $T$. laticeps nests in wood cavities, boring wood cavity for nest construction, as has been observed in species of Lithurgus, Lithurgopsis, and Microthurge. Thus, this species can be considered a carpenter bee.

Nest cells are unlined and provisioned almost exclusively with pollen of the cactus $O$. sulphurea. $T$. laticeps is a univoltine species that overwinters inside a hard cocoon. It can share the nest with other solitary bee species, suffers little nest parasitism and in spite of the low frequency of ant attacks is highly vulnerable to them (100\% mortality).

Both foraging observations in flowers and nest provisioning indicate that this species is oligolectic, as it uses mostly pollen of O. sulphurea, occurs only in locations where this plant species is present, and builds its nests only in the particular season when $O$. sulphurea is in bloom. It would be important to conduct studies of the nesting ecology of $T$. laticeps in other locations throughout its geographic range, to evaluate whether the close association to $O$. sulphurea is a local peculiarity or a general phenomenon.

Although T. laticeps feeds mostly on pollen (and possibly nectar) of $O$. sulphurea, it uses consistently pollen of $P$. flexuosa and $C$. arvense, which is likely an indication that females visit flowers of these species regularly. One explanation for this intriguing observation is that this pollen is a by-product of nectar foraging. For example, Rust et al. (2004) proposed that females of Lithurgus chrysurus foraged on some plant species mostly for nectar, which resulted in this species being consistently found at extremely low proportions in the nest pollen. Furthermore, oligolectic bees usually secure their nectar from many plant species while restricting themselves to a few species for pollen (Müller 1996). Another possible explanation is that some plant species are regularly visited because they offer pollen that is qualitatively different from the predominant pollen source. For instance, Lithurgus cornutus forages for pollen of Fabaceae (Güler and Sorkun 2007), which is presumably richer in protein and mineral content than pollen from other families (Baydar and Gürel 1998). In this case, we would expect the female's fitness to be correlated with the presence of the rare pollen species; however, this was not the case for T. laticeps. Because both $P$. flexuosa and $C$. arvense are known to be sources of nectar for insects like bees, butterflies, and dipterans (Andrada 2003; Beil et al. 2008; Naab and Tamame 2007), we think that the presence of this pollen in the provisions is more an expression of the female's nectar foraging behavior than an indication of the provision of a special food for larvae.

Our results on the nest architecture of $T$. laticeps suggest that it is similar to other Lithurgini and agrees with observations on Lithurgus, Lithurgopsis, and Microthurge (for example Rozen 2013; Rozen and Hall 2014, Garófalo et al. 1992). We believe that the anecdotic observations on T. bolithophilus (Sarzetti et al. 2012), especially the use of dung pads as substrate, are more a peculiarity of this species 
than a representation of the predominant behavior of the genus Trichothurgus. Beyond the Lithurginae, our observations on the nesting habits of T. laticeps may contribute to understanding the evolution of the nesting behavior and nest architecture in solitary bees. T. laticeps shares with other members of the Lithurginae and other basal groups in the Megachilidae the lack of a nest lining and the absence of foreign material to build nests, supporting the idea that these nest features are plesiomorphies (Flores-Prado et al. 2010; Litman et al. 2011). Litman et al. (2011) suggested that all lithurgines lack a cell lining, and that they instead dig burrows in wood or stems to protect their pollen provisions from desiccation. We think that this explanation is insufficient, as other megachilid bee species use aboveground cavities under the same environmental conditions, and line their cells with foreign materials (Bosch et al. 1993; Gonzalez and Griswold 2013). However, the ability to build nests in wood cavities in the Lithurginae should not be considered a primitive condition, as this behavior requires specific morphological structures, such as strong mandibles, and is absent in other basal taxa of the Megachilidae and the basal Apidae as well. In fact, this behavior has been observed only in the Xylocopinae (Apidae), which suggests a convergent evolution of wood boring for nest construction in these two distantly related groups, as has been proposed by Flores-Prado et al. (2010).

The pollen mass is neither worked nor manipulated by the females of lithurgine bees, as is also the case with females of Fideliinae bees, the most basal subfamily in the Megachilidae (Litman et al. 2011). The narrow host range of the Lithurginae clearly appears to be a primitive condition in the Megachilidae (Litman et al. 2011), although some lithurgine species use more than one kind of resources (Güler and Sorkun 2007). Thus, we agree with Litman et al. (2011) in that it seems reasonable to suppose that the unworked pollen mass and the oligolecty are plesiomorphic characters.

As to the functional consequences of our observations, we believe that two behavioral features of $T$. laticeps favor the survival of its immature stages. One is the close synchrony of its nesting phenology with the flowering phenology of O. sulphurea; the other is the structure of the cocoon. Regarding phenological synchrony, pollen provisioning by the female occurs continuously over a short period that overlaps with O. sulphurea's flowering phenology. This cactus species seems to be a reliable pollen source, as in all study years, we observed flowers independently of inter-annual climatic variability, and as each flower offers substantially more pollen grains than flowers of other plant species. Regarding the cocoon structure, it represents an extremely hard structure lacking a nipple (thickened spot), which presumably can be cut only by the strong mandibles of a carpenter bee. Rozen and Hall (2014) analyzed in detail the cocoon structure of Lithurgopsis apicalis, concluding that the broad, flat, slightly domed cocoon front is tightly bound to the burrow wall and serves to block parasites. Thus, we suggest that the cocoon not only provides protection to immature stages but also prevents parasites from leaving the cocoon, preventing further attacks (at the population level for the next generation). These cocoon features might represent an evolutionary novelty, as the lithurgines are the only bee group with this unusual cocoon structure.

\section{ACKNOWLEDGMENTS}

Research was funded through grants from CONICET - Consejo Nacional de Investigaciones Científicas y Técnicas (PIP 6564 and 2781) and Agencia Nacional de Promoción Científica y Tecnológica (PICT 20805 and 2010-2779). The following colleagues helped with taxonomic identifications: Gabriel Melo and Juan Pablo Torreta (Hymenoptera) and José Ambrosetti (plants). We thank Georgina Amico for help in field and laboratory activities, Federico Dell Agnola for drawings included in this manuscript, Erica Stevani for the photo with $T$. laticeps foraging, Roberto Kiesling for discussions on the response of Opuntia's stamina to mechanical stimuli, and Natacha Chacoff, Víctor H. González, Belén Maldonado, Gabriel Melo, Hugo Marrero, and Juan Pablo Torretta for comments on the manuscript.

Ecologie et biologie de la nidification de l'abeille Trichothurgus laticeps (Hymenoptera: Megachilidae) dans une réserve du désert de Monte dans le centreouest de l'Argentine 
Relation plante-hôte / spécialisation / Lithurginae / structure du nid / relations phylogénétiques / abeille solitaire

\section{Ökologie und Nestbiologie der holzbohrenden Biene Trichothurgus laticeps (Hymenoptera: Megachilidae) in einem Monte-Wüstenreservat im Mittelwesten von Argentinien}

Wirtspflanzenspezialisierung / Lithurginae / Nistverhalten und Neststruktur / phylogenetische Beziehungen / solitäre Bienen

\section{REFERENCES}

Andrada, A.C. (2003) Flora utilizada por Apis mellifera L. en el sur del Caldenal (Provincia Fitogeográfica del Espinal), Argentina. Rev. Mus. Argentino Cienc. Nat. 5, 329-336

Ascher J., J. Pickering. (2010) Bee Species Guide (Hymenoptera: Apoidea: Anthophila) http:// www.discoverlife.org.

Baydar, H., Gürel, F. (1998) The pollen collection activity and preference of honey bees (Apis mellifera) in the natural habitat of Antalya and some morphological and quality properties of different pollen types. Turk. J. Agric. For. 22, 475-482

Beil, M., Horn, H., Schwabe, A. (2008) Analysis of pollen loads in a wild bee community (Hymenoptera: Apidae) - a method for elucidating habitat use and foraging distances. Apidologie 39(4), 456-467

Blüthgen, N., Menzel, F., Blüthgen, N. (2006) Measuring specialization in species interaction networks. BMC Ecol. 6(1), 9-21

Bosch, J., Vicens, N., Blas, M. (1993) Análisis de los nidos de algunos Megachilidae nidificantes en cavidades preestablecidas (Hymenoptera, Apoidea). Orsis 8, 53-63

Buschini, M., Rigon, J., Cordeiro, J. (2009) Plants used by Megachile (Moureapis) sp. (Hymenoptera: Megachilidae) in the provisioning of their nests. Braz. J Biol 69 (4), 1187-1194

Claude-Joseph, F. (1926) Recherches biologiques sur les Hyménoptères du Chili (Mellifères). Ann. Sci. Nat. Zool. 9, 113-268

Chacoff, N.P., Vázquez, D.P., Lomáscolo, S.B., Stevani, E.L., Dorado, J., et al. (2012) Evaluating sampling completeness in a desert plant-pollinator network. J. Anim. Ecol. 81 (1), 190-200

Danforth, B.N., Cardinal, S., Praz, C., Almeida, E.A., Michez, D. (2013) The impact of molecular data on our understanding of bee phylogeny and evolution. Annu. Rev. Entomol. 58, 57-78

Díaz, L., Cocucci, A. (2003) Functional gynodioecy in Opuntia quimilo (Cactaceae), a tree cactus pollinated by bees and hummingbirds. Plant Biol. 5 (5), 531-539
Dorado J. (2011) Plant-pollinator interactions from the pollinator's perspective: Floral diversity, solitary bee reproduction and its specialization. Doctoral thesis. Facultad de Ciencias Exactas y Naturales, Universidad de Buenos Aires, CABA

Dórea, M.C., Aguiar, C.M.L., Figueroa, L.E.R., Lime e Lima, L.C., dos Santos, F.A.R. (2013) A study of pollen residues in nests of Centris trigonoides Lepeletier (Hymenoptera, Apidae, Centridini) in the Caatinga vegetation, Bahia, Brazil. Grana 52 (2), 122-128

Flores-Prado, L., Flores, S.V., McAllister, B.F. (2010) Phylogenetic relationships among tribes in Xylocopinae (Apidae) and implications on nest structure evolution. Mol. Phylogenet. Evolution 57 (1), 237-244

Garófalo, C., Camillo, E., Campos, M., Serrano, J. (1992) Nest re-use and communal nesting in Microthurge corumbae (Hymenoptera, Megachilidae), with special reference to nest defense. Insectes Soc. 39 (3), 301-311

Gonçalves, L., Silva, C., Buschini, M.L.T. (2012) Collection of pollen grains by Centris (Hemisiella) tarsata Smith (Apidae: Centridini): is C. tarsata an oligolectic or polylectic species? Zool. Stud. 51, 195-203

Gonzalez, V.H., Griswold, T., Praz, C.J., Danforth, B.N. (2012) Phylogeny of the bee family Megachilidae (Hymenoptera: Apoidea) based on adult morphology. Syst. Entomol. 37 (2), 261-286

Gonzalez, V.H., Griswold, T.L. (2013) Wool carder bees of the genus Anthidium in the Western Hemisphere (Hymenoptera: Megachilidae): diversity, host plant associations, phylogeny, and biogeography. Zool. J. Linn. Soc. 168 (2), 221-425

Güler, Y., Sorkun, K. (2007) Pollen preferences of Hoplosmia bidentata and Lithurgus cornutus (Hymenoptera: Megachilidae). Entomol. Fennica 18 (3), 174-178

Hedtke, S.M., Patiny, S., Danforth, B.N. (2013) The bee tree of life: a supermatrix approach to apoid phylogeny and biogeography. BMC Evol. Biol. 13 (1), 138-151

Litman, J.R., Danforth, B.N., Eardley, C.D., Praz, C.J. (2011) Why do leafcutter bees cut leaves? New insights into the early evolution of bees. Proc. R. Soc. B. 278 (1724), 3593-3600

Louveaux, J., Maurizio, A., Vorwohl, G. (1978) Methods of Melissopalynology. Bee World 59(4), 139-157

Maurizio, J., Louveaux, A., Vorwohl, G. (1978) Les méthodes de la mélisso-palynologie. Apidologie 1, 211-227

Michener, C.D. (2007) The bees of the world. Johns Hopkins University Press, Maryland

Moure J.S., G.A.R. Melo. (2012) Catalogue of Bees (Hymenoptera, Apoidea) in the Neotropical Region. http://www.moure.cria.org.br/catalogue

Müller, A. (1996) Host-plant specialization in western palearctic anthidine bees (Hymenoptera: Apoidea: Megachilidae). Ecol. Monogr. 66, 235-257 
Naab, O., Tamame, M.A. (2007) Flora apícola primaveral en la región del Monte de la Provincia de La Pampa (Argentina). Bol. Soc. Argent. Bot. 42, 251-259

Neff, J. (2003) The passionflower bee: Anthemurgus passiflorae. J. Newsl. Passiflora Soc. Int. 13, 7-9

Neff, J., Simpson, B.B. (1992) Partial bivoltinism in a ground-nesting bee: the biology of Diadasia rinconis in Texas (Hymenoptera, Anthophoridae). J. Kans. Entomol. Soc. 65, 377-392

R Core Team (2015) R: A language and environment for statistical computing. http://www.R-project.org/

Roig-Alsina, A., Michener, C.D., Silveira, F.A. (1993) Studies of the phylogeny and classification of longtongued bees (Hymenoptera: Apoidea). Univ. Kansas Sci. Bull. 55 , 123-173

Roughgarden, J. (1974) Niche width: biogeographic patterns among Anolis lizard populations. Am. Nat. 108, 429-442

Rozen, J.G. (1973) Immature stages of lithurgine bees with descriptions of the Megachilidae and Fideliidae based on mature larvae (Hymenoptera, Apoidea). Am. Mus. Novitates 2527, 1-14

Rozen Jr., J.G. (2013) Larval development and nesting biology of the adventive wood-nesting bee Lithurgus ( $L$.) chrysurus Fonscolombe (Hymenoptera: Megachilidae: Lithurgini). Am. Mus Novitates 3774, 20-40

Rozen Jr., J.G., Hall, H.G. (2014) Nest site selection and nesting behavior of the bee Lithurgopsis apicalis (Megachilidae: Lithurginae). Am. Mus. Novitates 3796, 1-24

Rust, R.W., Cambon, G., Grossa, J.P.T., Vaissière, B.E. (2004) Nesting biology and foraging ecology of the wood-boring bee Lithurgus chrysurus (Hymenoptera: Megachilidae). J. Kans. Entomol. Soc. 77, 269-279
Sargeant, B.L. (2007) Individual foraging specialization: niche width versus niche overlap. Oikos 116, 14311437

Sarzetti, L., Genise, J., Sanchez, M.V. (2012) Trichothurgus bolithophilus sp. n. (Hymenoptera, Megachilidae) a bee nesting in horse manure pads in Patagonia, Argentina. J Hymenoptera Res 29, 1-14

Schlindwein, C., Pick, R.A., Martins, C.F. (2009) Evaluation of oligolecty in the Brazilian bee Ptilothrix plumata (Hymenoptera, Apidae, Emphorini). Apidologie 40, 106-116

Schlindwein, C., Wittmann, D. (1997) Stamen movements in flowers of Opuntia (Cactaceae) favour oligolectic pollinators. Plant Syst. Evol. 204, 179-193

Sipes, S.D., Tepedino, V.J. (2005) Pollen host specificity and evolutionary patterns of host switching in a clade of specialist bees (Apoidea: Diadasia). Biol. J. Linn. Soc. 86, 487-505

Spegazzini, C. (1900) Notas botánicas. An. Soc. Cient. Argentina 49, 122-125

Vázquez, D.P., Chacoff, N.P., Cagnolo, L. (2009) Evaluating multiple determinants of the structure of plant-animal mutualistic networks. Ecology 90 , 2039-2046

Vázquez, D.P., Lomáscolo, S.B., Maldonado, M.B., Chacoff, N.P., Dorado, J., et al. (2012) The strength of plant-pollinator interactions. Ecology 93, 719-725

Wickham, H. (2009) ggplot2: elegant graphics for data analysis. Springer, New York

Zaccarelli, N., Bolnick, D.I., Mancinelli, G. (2013) RInSp: an $r$ package for the analysis of individual specialization in resource use. Methods Ecol. Evol. 4, 10181023 